\title{
Signs and Symptoms Indicative of Community-Acquired Pneumonia in Infants under Six Months
}

\author{
Maria de Fátima Bazhuni Pombo March and \\ Clemax Couto Sant'Anna
}

Martagão Gesteira PediatricInstitute, Dept. of Pediatrics, Medical
School of Federal University of Rio de Janeiro; Rio de Janeiro, RJ, Brazil

\begin{abstract}
Objective: Evaluation of the clinical signs and symptoms predicting bacterial and viral pneumonia, in accordance with the Brazilian National Control Program for Acute Respiratory (ARI). Methods: Observational prospective study. Seventy-six children from birth to six months of age who had pneumonia were studied in the emergency room. The patients were subdivided into two groups, based on radiological findings (gold-standard): 47 had bacterial pneumonia, and 29 had viral pneumonia. The frequencies, sensitivities, and specificities of the signs and symptoms were evaluated. Results: The sensibilities and sensitivities of general findings in bacterial pneumonia were, respectively: fever $53.2 \% / 40.0 \%$; hypoactivity $68.4 \% / 55.6 \%$ and prostration detected by the doctor $72.7 \% / 55.0 \%$. The same findings in viral pneumonias showed, respectively: $37.9 \% / 40.0 \%, 66.7 \% / 55.6 \%$ and $66.7 \% / 55.6 \%$. The sensibilities and sensitivities of respiratory findings in bacterial pneumonia were, respectively: coughing 66.0/38.1\%, Respiratory rate $=\mathbf{5 0}$ ripm $\mathbf{7 6 . 6} \% / 38.1 \%$, altered respiratory auscultation $91.3 \% / 10.5 \%$, and chest indrawing 46.7\%/80.0\%. The same findings in viral pneumonias were, respectively: $69.0 \% /$ $38.1 \%, 86.2 \% / 38.1 \%, 85.7 \% / 10.5 \%$ and $44.8 \% / 80.0 \%$. Conclusion: Analysis of signs and symptoms in each group did not distinguish bacterial from viral pneumonia. Our findings reinforce the adequacy of the ARI program in Brazil, which gives an early diagnosis of pneumonia, independent of its etiology.

Key Words:
\end{abstract}

Pneumonia is important in the developing countries, due to its high lethality in children under five years old, especially among infants [1-4]. Infants may present unspecific signs and symptoms that hinder the diagnosis [5-8].

Our study was motivated by the difficulty of diagnosing pneumonia in infants, especially those under six months. Our aim was to evaluate the signs and symptoms indicative of community-acquired pneumonia established by the Acute Respiratory Infections (ARI) Program of the Ministério da Saúde (MS) do Brasil

Received on 08 August 2004; revised 22 January 2005. Address for correspondence: Dr. Clemax C. Sant'Anna. Rua Barão de Mesquita, 459, bloco 2. apt. 102, Tijuca. Zip code: 20540-001, Rio de Janeiro, RJ, Brazil. Fax: (55 21) 2590-4891.

E-mail: clemax@vetor.com.br

The Brazilian Journal of Infectious Diseases 2005;9(2):150-155 (C) 2005 by The Brazilian Journal of Infectious Diseases and Contexto Publishing. All rights reserved.
[Brazilian Health Ministry] [9-10]. This program diagnoses pneumonia solely on the basis of clinical findings obtained by visual inspection and timing of the respiratory rate and is based on international recommendations from the World Health Organization [10]. We also examined the prevalence and respiratory findings of patients with bacterial and viral pneumonia.

\section{Material and Methods}

The study was performed at the Pediatric Emergency Service of the Instituto de Puericultura e Pediatria Martagão Gesteira (IPPMG) of the Universidade Federal do Rio de Janeiro (UFRJ), from January 1 to December 31, 1996. We made a descriptive crosssectional study, with prospective data collection, designed to evaluate diagnostic criteria for communityacquired pneumonia. 
The children, who ranged in age from zero to six months, had signs and symptoms of acute respiratory infection (ARI), as defined by the guidelines of the Brazilian Health Ministry (MS) [8,9], with suspected acute pneumonia and consequently were submitted to chest radiography.

The total number of children from 0 to 12 years old attended at the Emergency Service during the 12-month period was 9,711. Using random sampling, 1,648 bulletins were selected. These included 113 ARI patients from zero to six months old, among which 76 had pneumonia. Eighteen pediatricians who had received training in the IRA Program of the MS up to six months before were available for data collection.

The respiratory rate (RR) was measured with a chronometer, by observation of the thoracic chest movements or by auscultation of the respiratory sounds with a stethoscope for one minute. The values of respiratory incursions per minute (ripm) were categorized according to World Health Organization (WHO) guidelines for the diagnosis of pneumonia in this age range: $R R=50$ ripm $(0-2 \mathrm{~m})$ and $R R=60$ ripm $(2-6 m)[5,11,12]$. The pulmonary auscultation was considered abnormal whenever that there was reduction or abolition of the vesicular murmur, coarse crackles, fine crackles, rhonci, wheezing, or associations of some of these noises.

$\mathrm{X}$-ray analysis allowed categorization into normal and abnormal. Abnormality was designated when any of the following images was presented: homogeneous or heterogeneous opacity, interstitial infiltrate, hyperinflation or pleural effusion. Normal was when no alteration was displayed. Radiological findings with no relation to the respiratory tract were not necessarily considered as abnormalities [5,13,14].

The cases of pneumonia $(n=76)$, based on the radiological aspect (gold-standard), were subdivided according to the possible etiology. Among these patients, 47 presented condensation or pleural effusion, considered cases of bacterial pneumonia, and $29 \mathrm{had}$ infiltrate, considered cases of viral pneumonia.

The Institutional Review Board (IRB) of the IPPMG-UFRJ approved the research. Patients with radiological images of hyperinflation were not included in the groups. Those who had chest radiographies without alterations in the pulmonary fields were classified as free of pneumonia.

The data were compiled on a computer utilizing the EPI.INFO.6 program.

Categorical variables were described with their corresponding frequency distribution. The continuous variables were described by central tendency and dispersion measures as well as by the calculation of the odds ratio (OR) and the corresponding 95\% confidence interval (CI). Sensitivity (S), specificity (Sp) and confidence intervals of $95 \%$ (CI 95\%) were determined for the diagnosis of pneumonia, according to convent [5].

\section{Results}

The 76 patients with pneumonia, based on the radiological pattern, were divided into two groups:

a) Group with bacterial pneumonia: 47 children (Table 1). b) Group with viral pneumonia: 29 children (Table 2).

\section{Discussion}

We adopted the definition of pneumonia based on chest radiography, because this is generally considered the gold standard for diagnosis [10,13-15]. Opacity and pleural effusion in children suggests a diagnosis of bacterial pneumonia, possibly by pneumococcus or by Haemophilus influenzae, and would justify the institution of antibiotic therapy in developing countries, [9,14-16]. Interstitial infiltrates are almost always associated with non-bacterial processes. Even in developed countries, no safe method is available for the etiological diagnosis of pneumonia, and so radiological diagnosis is still the most commonly employed [17-19].

Fever gave a sensitivity of around $50 \%$ in children with bacterial pneumonia, and a lower sensitivity, $38 \%$, in those with viral pneumonia; possibly this is due to less severe cases, given that such infections usually have a febrile course or a low fever $[7,10,20]$. In both groups 
Table 1. General data and respiratory findings in infants from zero to six months old with bacterial pneumonia.IPPMG. UFRJ. Rio de Janeiro, Brazil, 1996

\begin{tabular}{lcccccc}
\hline General data & N/T & $\%$ & $\begin{array}{c}\text { Sensitivity } \\
(\%)\end{array}$ & CI 95\% & $\begin{array}{c}\text { Specificity } \\
(\%)\end{array}$ & CI 95\% \\
\hline Fever & $25 / 47$ & 53.2 & 53.2 & $38.2-67.6$ & 40 & $20-63.6$ \\
$\begin{array}{l}\text { Hypoactivity } \\
\text { or irritability }\end{array}$ & $26 / 38$ & 55.3 & 68.4 & $51.2-82$ & 55.6 & $31.3-77.6$ \\
$\begin{array}{l}\text { Prostration } \\
\text { Coughing }\end{array}$ & $24 / 33$ & 51 & 72.7 & $54.2-86.1$ & 55 & $32-76.2$ \\
$\begin{array}{l}\text { Dyspnoea } \\
\text { (reported ) }\end{array}$ & $31 / 47$ & 66 & 66 & $50.6-78.7$ & 38.1 & $19-61.3$ \\
$\begin{array}{l}\text { Altered respiratory } \\
\text { auscultation }\end{array}$ & $42 / 46$ & 68.1 & 68.1 & $52.7-80.5$ & 47.6 & $26.4-69.7$ \\
$\begin{array}{l}\text { RR } \geq 50 \text { ripm } \\
\text { RR } \geq \text { 60ripm }\end{array}$ & $36 / 47$ & 76.6 & 76.6 & $61.6-87.2$ & 38.1 & $19-61.3$ \\
Chest indrawing & $21 / 47$ & 55.3 & 55.3 & $40.2-69.5$ & 66.7 & $43.1-84.5$ \\
\hline
\end{tabular}

$\mathrm{N}=$ number of cases $\mathrm{T}=$ total number of cases $\mathrm{CI}=$ confidence interval; $\mathrm{RR}=$ respiratory rate; ripm = respiratory incursions per minute.

Table 2. General data and respiratory findings in infants from zero to six months old with viral pneumonia.IPPMG. UFRJ. Rio de Janeiro, Brazil, 1996.

\begin{tabular}{|c|c|c|c|c|c|c|}
\hline General data & $\mathbf{N} / \mathbf{T}$ & $\%$ & Sensitivity (\%) & CI 95\% & Specificity (\%) & CI 95\% \\
\hline Fever & $11 / 29$ & 37.9 & 37.9 & $21.3-57.6$ & 40 & $20-63.6$ \\
\hline $\begin{array}{l}\text { Hypoactivity } \\
\text { or irritability }\end{array}$ & $16 / 24$ & 62 & 66.7 & $44.7-83.6$ & 55.6 & $31.3-77.6$ \\
\hline Prostration & $13 / 19$ & 44.8 & 66.7 & $44.7-83.6$ & 55.6 & $31.3-77.6$ \\
\hline Coughing & $20 / 29$ & 69 & 69 & $49-84$ & 38.1 & $19-61.3$ \\
\hline $\begin{array}{l}\text { Dyspnoea } \\
\text { (reported) }\end{array}$ & $21 / 29$ & 72.4 & 72.4 & $52.5-86.6$ & 47.6 & 26.4- 69.7 \\
\hline $\begin{array}{l}\text { Altered respiratory } \\
\text { auscultation }\end{array}$ & $24 / 28$ & 89.6 & 85.7 & $66.4-95.3$ & 10.5 & $1.8-34.5$ \\
\hline $\mathrm{RR} \geq 5$ 0ripm & $25 / 29$ & 86.2 & 86.2 & $67.4-95.5$ & 38.1 & $19-61.3$ \\
\hline $\mathrm{RR} \geq 6$ 6ripm & $20 / 29$ & 69 & 69 & $49-84$ & 66.7 & $43.1-84.5$ \\
\hline Chest indrawing & $13 / 29$ & 44.8 & 44.8 & $27-64$ & 80 & 51.4- 94.7 \\
\hline
\end{tabular}

$\mathrm{N}=$ number of cases $\mathrm{T}=$ total number of cases $\mathrm{CI}=$ confidence interval $\mathrm{Vp}=$ predictive value; $\mathrm{RR}=$ respiratory rate; ripm $=$ respiratory incursions per minute. 
the specificity was low (40\%). As also found in other studies [5,21-23], fever is not a good indicator of pneumonia,

Altered activity, including hypoactivity and irritability, was a symptom with good sensitivity (around 67\%) and specificity (56\%), in both the bacterial and viral groups. Prostration was a more sensitive sign in bacterial than in viral pneumonia. These signs, albeit unspecific, proved to be good predictors of bacterial pneumonia. In the viral pneumonia group, the degree of activity did not give such precision. Published studies evaluating this symptom were not found.

Coughing and complaints of respiratory difficulty are considered entry criteria for pneumonia in accordance with WHO Guidelines [5,9], and they were good predictors of pneumonia in our group of patients. Most of the cases would be detected if coughing and respiratory difficulties were the only entry criteria considered. Nevertheless, coughing may not always be regarded by the family as a sign to seek medical attention. Respiratory difficulty is a clear sign of severity, however, it is absent in many infants with pneumonia. Children with other signs and symptoms were submitted to X-rays and diagnosed as cases of pneumonia by the doctors who evaluated them.

In 1994, Singhi et al. [7] studied children under two months old and observed that pneumonia occurred without coughing or respiratory difficulty in $21 \%$ of the cases. Crain et al. [6] observed absence of coughing in only $4 \%$ of babies with fever and radiological pneumonia; they concluded that, in the absence of respiratory signs, the chest radiography would probably be normal. Losek et al. [13], in a study of 209 babies with fever, found 16 with pneumonia, defined as any radiological infiltrate, with coughing in $56 \%$. These percentages were higher than ours, though since fever was an entry criterion infectious diseases of the respiratory tract of various other origins could have been included.

The complaint of wheezing by the parents, frequently found in viral pneumonia, was not analyzed because it was reported in only four cases.

Any abnormality on auscultation of the chest showed high sensitivity and low specificity in both groups. The greatest sensitivity values were detected in the patients with bacterial pneumonia, but this exam did not allow discrimination between the viral and the bacterial cases [14-19]. Abnormal auscultation of the chest is not included in WHO guidelines, because is not a good predictor of pneumonia in children [20-24].

The $\mathrm{RR} \geq 50$ ripm showed high sensitivity, around $80 \%$, and low specificity. This result is in accordance with the orientation of WHO guidelines, which determines the value of $\mathrm{RR} \geq 50 \mathrm{ripm}$ as the best indicator of pneumonia in children from 2 to 11 months of age $[5,9,24]$. However, the $\mathrm{RR} \geq 50$ ripm did not differentiate cases of bacterial pneumonia from the viral ones. Thus, children without bacterial pneumonia would receive an antibiotic unnecessarily. Nevertheless, because of its high sensitivity, this is a good entry criterion for pneumonia in children from zero to six months in regions with few health resources.

Apparently, other signs and symptoms are important for the diagnosis of bacterial pneumonia and the prescription of antibiotics [25,26]. In large urban centers the participation of a well-trained pediatrician would be important for the therapeutic decision, in order to avoid the unnecessary use of antibiotics.

In our case study, an $R R \geq 60$ ripm was a more sensitive sign for identification of children with viral than for bacterial pneumonia. If compared with the $\mathrm{RR} \geq$ 50 ripm, there is a loss in sensitivity, but a gain in specificity and precision, as indicative of bacterial or viral pneumonia. Thus, though it adversely affects the entry criteria of cases of ARI, less antibiotics would be prescribed unnecessarily. However, in poor regions, the value of $R R \geq 50$ ripm would be preferable, as it guarantees greater coverage of cases.

Chest indrawing showed sensitivity with lower values when there was increased RR in all the patients. It is a sign of the severity of pneumonia and a predictor for hospitalization $[9,24]$. It was less frequent in our study, giving less sensitivity than the values of RR. But the high specificity demonstrate that when it is present, even alone, chest indrawing is quite suggestive of a diagnosis of pneumonia, although it also did not allow differentiation of bacterial from viral pneumonia. Chest indrawing could be a good indicative sign of severity and necessity of hospitalization, bearing in mind that 
this conduct would not necessarily imply prescription of antibiotics, given that severe cases of viral etiology could be included.

In our study, the $\mathrm{RR} \geq 60$ ripm criterion gave a better combination of sensitivity $(69 \%)$ and specificity (67\%) in the viral pneumonia cases. Perhaps the greater specificity values obtained with $\mathrm{RR} \geq 60$ ripm would justify the employment of this single predictor of pneumonia for children under six months old. Nevertheless, due to the potential severity of pneumonia in children under six months old, the value of $R R \geq 50$ ripm would be the most suitable for a diagnosis of pneumonia whenever other complementary methods are not available. Singhi et al. [7] reached the same conclusion in a study of children two to six months old in India and in another study of children under two months. However, the use of this value of RR alone for the diagnosis of pneumonia would lead to treatment with antibiotics of many children who do not have bacterial pneumonia. In the face of the difficulties encountered in diagnosis, we conclude, as do Mulholand et al. [10] and Singhi et al. [7], that the clinical judgment of a pediatrician with access to chest radiography leads to the most appropriate definition of pneumonia in these babies. In any case, by considering $\mathrm{RR} \geq 50$ ripm, associated or not with subcostal indrawing for diagnosing of pneumonia, one avoids losing cases, even though there is an overestimation of the diagnosis on certain occasions.

In our study, although we found lower sensitivity and specificity values for $R R \geq 50$ ripm or for subcostal indrawing, these reflect the routine in the emergency room. The lower sensitivity of subcostal indrawing, for example, is explained by the greater frequency of cases of non-severe pneumonia in day-to-day medical practice. This shows the importance of testing predictor signs and symptoms of pneumonia. They should be tested and applied in accordance with the results in each community, region or country, respecting their peculiarities. In Brazil, and in other developing countries, clinical diagnosis is still the most important tool for controlling mortality due to pneumonia. Our findings can contribute to a validation of case management of pneumonia in children.

\section{Conclusions}

We found that a high RR and subcostal indrawing are suitable for the diagnosis of pneumonia, but not for discrimination between bacterial and viral pneumonia, based on comparisons with the radiological criteria. The predominant hypothesis of viral pneumonia in these infants should not be ignored, even though we are in a developing country, supposedly with a greater prevalence of bacterial pneumonia in children under five years old [14,17,21,27]. Even so, the utilization of WHO guidelines in regions lacking in health resources avoids deaths, which is the prime objective in cases of bacterial pneumonia. We regard etiological studies of pneumonia in this age range to be essential. There is a need to develop better technologies for differentiation between bacterial and viral pneumonias, for thus it would be possible to reduce the abusive use of antibiotics, avoiding the development of bacterial resistance [26-32], a problem already identified in various countries.

\section{Acknowledgments}

We thank Prof. Uéleres Braga, Dr. Verônica Edelhof and the medical staff of the Emergency Service of IPPMG for technical support.

\section{References}

1. Black R.E., Morris S.S., Bryce J. Where and why are 10 million children dying every year? Lancet 2003;28:2226-34.

2. Sazawal S., Black R.E. Pneumonia Case Management Trials Group. Effect of pneumonia case management on mortality in neonates, infants and preschool children: a meta-analysis of community-based trials. Lancet Infect Dis 2003; 3:547-56.

3. Rasmussen Z., Pio A, Enarson P. Case management of childhood pneumonia in developing countries: recent relevant research and current initiatives. Int $\mathbf{J}$ Tuberc Lung Dis 2000;4:807-26.

4. Leowsky J. Mortality from acute respiratory infections in children under 5 years of age: global estimates. Rapp Trimest Statist Sanit Mond 1986;39:138-44. 
5. World Health Organization (WHO). Technical bases for the WHO recommendations on the management of pneumonia in children at first level health facilities. Geneva, 1991, WHO \ARIY91.20.

6. Crain E.F., Bulas D., Bijur P.E., et al. Is a chest radiograph necessary in the evaluation of every febrile infant less than 8 weeks of age? Pediatrics 1991;88:821-4.

7. Singhi S., Dhawan A., Kataria S., et al. Clinical signs of pneumonia in infants under 2 months. Arch Dis Child 1994;70:413-7.

8. Leventhal J.M. Clinical predictors of pneumonia as a guide to ordering chest roentgenograms. Clin Pediatr 1982;21:730-4.

9. Brasil. Secretaria de Assistência à Saúde. Coordenação Materno-Infantil. Manual de Assistência e Controle das Infecções Respiratórias Agudas (IRA). 4 ed. Brasília. Centro de Documentação do MS. 1994.

10. March MFBP. Estudo de sinais e sintomas preditivos de pneumonia na infância e sua utilização em programas de controle das infecções respiratórias agudas (IRA). In: Benguigui Y. Investigações operacionais sobre o controle das infecções respiratórias agudas. Washington: OPAS, 1997 p. 213-222. Série HCT LAIEPI-2.

11. Mulholland E.K., Simões E.A.F., Costales M.O.D., et al. Standardized diagnosis of pneumonia in developing countries. Pediatr Infect Dis J 1992;11:77-81.

12. Organization Mondiale de la Santé. programme de lutte contre les infections respiratoires aignes. Signes cliniques et agents etiologiques des pneumonies, infections generalisées et meningites chez le nourisson. Rapport d'une réunion. Génève, 21-24 novembre 1989. WHO/ARI/90.14.

13. Margolis P., Gadomski A. Does this baby have pneumonia? JAMA 1998;279:308-13.

14. Maxson S., Jacobs R.F. Guidelines for evaluating children with lower respiratory tract infections. J Respirat Dis 1994; 15:453-66.

15. Singhi S., Dhawan A., Kataria S., et al. Validity of clinical signs for the identification of pneumonia in children. Ann Trop Paediatr 1994; 14:53-8.

16. Adegbola R.A., Obaro S.K. Diagnosis of childhood pneumonia in the tropics. Ann Trop Med Parasitol 2000;94:197-207.

17. Shann F.A. Etiology of severe pneumonia in children in developing countries. Pediatr Infect Dis J 1986;5:247-52.

18. Campbell H. Physical signs of diffuse airways obstruction and lung distention. Thorax 1969;24:1-3.

19. Mc Cracken G.H. Jr. Diagnosis and management of pneumonia in children. Pediatr Infect Dis J 2000;19;924-8.

20. Victora C.G., Smith P.G., Vaughan J.P., et al. Risk factors for deaths due to respiratory infections among Brazilian infants. Int J Epidemiol 1989;18:901-8.
21. Victora C.G., Fuchs S.C., Flores J.A.C., et al. Risk factors for pneumonia among children in a Brazilian metropolitan area. Pediatrics 1994;93:977-85.

22. Sant' Anna C.C., Cunha A.J.A.L., Dalcomo M.P. Infecções respiratórias agudas. Rio de Janeiro, Cultura Médica, 1989:63p.

23. Kauchali S., Rollins N., Bland R., Van Den Broeck J. Maternal perceptions of acute respiratory infections in children under 5 in rural South Africa. Trop Med Intern Health 2004;9:644-50.

24. Ruuskamen O., Mertsola J. Childhood communityacquired pneumonia. Semin Respir Infect 1999;14:16372.

25. Kabra S.K., Singhal T., Lodha R. Pneumonia. Indian J Pediatr 2001;68(suppl 3):19-23.

26. Rodrigues J.C., Silva Filho L.V.F., Bush A. Diagnóstico etiológico das pneumonias: uma visão crítica. J Pediatr (Rio de J.) 2002;78(supl 2):129-40.

27. March MFBP, Sant' Anna C.C. Resistência bacteriana do pneumococo e suas implicações no tratamento das pneumonias na infância. Pediatria Atual 1999;12:32-8.

28. Cunha B.A. Therapeutic implications of antibacterial resistance in community-acquired respiratory tract infections in children. Infection 2004;32:98-108.

29. McIntosh K. Community-acquired pneumonia in children. N Engl J Med 2002;346:430-7.

30. British Thoracic Society. British Thoracic Society guidelines for the management of community acquired pneumonia in childhood. Thorax 2002;57(suppl I):11-24.

31. Ibiapina C.C., Alvim C.G., Rocha F.G., et al. Pneumonias comunitárias na infância: etiologia, diagnóstico e tratamento. Rev Med Minas Gerais 2004;14(supl 1):S19-S25.

32. Carvalho C.M.N., Marques H.H.S. Recomendação da Sociedade Brasileira de Pediatria para antibioticoterapia da criança e adolescente com pneumonia comunitária2002- http://www.sbp.com.br/ 